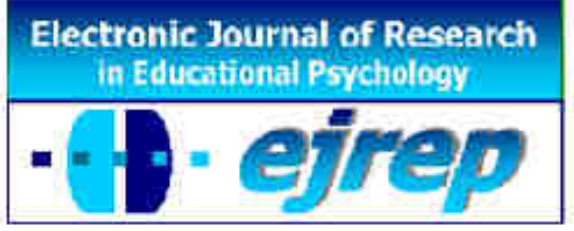

\title{
Resilient learners in schools serving poor communities
}

\section{G. Frempong ${ }^{1}$, M. Visser ${ }^{1}$, Nosisi Feza $^{2}$, L. Winnaar ${ }^{1}$, S. Nuamah ${ }^{3}$}

${ }^{1}$ Education and Skills Development Unit, Human Sciences Research Council, Pretoria

${ }^{2}$ Institute of Science Technology and Education, University of South Africa, Pretoria

${ }^{3}$ Women and Public Policy Program, Harvard Kennedy School of Government, USA

\section{South Africa/USA}

Correspondence: George Frempong. Human Sciences Research Council, 134 pretorius street, Pretoia. South Africa. E-mail: george.frempong@gmail.com

(C) Education \& Psychology I+D+i and Ilustre Colegio Oficial de Psicología de Andalucía Oriental (Spain) 


\begin{abstract}
Introduction. Through the the education for all initiative, a number of education systems have been able to provide access to their students at the basic education level. The major challenge is that most of these learners, especially, those from poor families who attend schools with limited resources are often not successful. However, in South Africa, quite a few of these learners succeed against all odds. We characterized these students as resilient and wonder what drives their success.
\end{abstract}

Method. Our analysis employed the South Africa 2011 Trends in International Mathematics and Science Study (TIMSS) and simple descriptive statistics to profile these resilient students. TIMSS was conducted by the International Association for the Evaluation of Educational Achievement (IEA). The TIMSS data included information on learners' socioeconomic background characteristics, their mathematics and science achievement, and their schooling characteristics. Using these data, we were able to estimate learners' socioeconomic status that was used as a proxy of poverty. We used a crosstabulation to identify poor learners in poor schools who were successful learning mathematics and developed the characteristics of these learners.

Results. Our profile indicates that a typical resilient learner is a girl who does not speak the language of classroom instruction at home. This learner tends to not only value and like mathematics but also expressed confidence about her ability to learn mathematics.

Discussion and Conclusion. The current South Africa policy to improve learning outcome for the poor tend to emphasise improvement of resources in schools serving the poor. Our findings demonstrate the importance of non-cognitive skills in developing resilience and the need to include professional development initiatives for teachers to develop capabilities to help learners to develop these skills.

Keywords: Resilience, poverty, non-cognitive skills, South Africa. 


\section{Alumnos resilientes en las escuelas que atienden a co- munidades pobres}

\section{Resumen}

Introducción. A través de la iniciativa de una educación para todos, una serie de sistemas de educación han sido capaces de proporcionar acceso a sus estudiantes en el nivel de educación básica. El principal reto es que la mayoría de estos alumnos, en especial, los de familias pobres que asisten a escuelas de escasos recursos a menudo no tienen éxito. Sin embargo, en África del Sur, un buen número de estos estudiantes tienen éxito contra todo pronóstico. Estos estudiantes están carazterizados como resilientes y nos preguntamos lo que les impulsa a su éxito.

Método. Nuestro análisis empleó las Tendencias en el Internacional de Matemáticas y Ciencias (TIMSS) de Sudáfrica 2011 y las estadísticas descriptivas simples para establecer un perfil de esos estudiantes resilientes. TIMSS se llevó a cabo por la Asociación Internacional para la Evaluación del Rendimiento Educativo (IEA). Los datos del TIMSS incluyen información sobre las características socioeconómicas de los alumnos de nuevo en tierra, sus matemáticas y ciencias, y su escolarización características. Usando estos datos, hemos sido capaces de estimar el nivel socioeconómico alumnos que se utilizó como factor próximo de la pobreza. Se utilizó una tabla de contingencia para identificar los estudiantes pobres en escuelas pobres que eran las matemáticas aprendizaje exitosas y desarrollaron las características de estos estudiantes.

Resultados. Nuestro perfil indica que un estudiante típico elástico es una niña que no habla el idioma de instrucción en el aula como en casa. Este alumnado tiende a no sólo a dar valor a las matemáticas, sino que también expresó confianza en su capacidad para aprender matemáticas.

Discusión y conclusión. La actual política de Sudáfrica para mejorar los resultados de aprendizaje para los pobres tienden a hacer hincapié en la mejora de los recursos en las escuelas que atienden a los pobres. Nuestros resultados demuestran la importancia de las habilidades no cognitivas en el desarrollo de la resiliencia y la necesidad de incluir iniciativas de desarrollo profesional para los maestros para desarrollar capacidades para ayudar a los estudiantes a desarrollar estas habilidades.

Palabras clave: Resiliencia, la pobreza, las habilidades no cognitivas, Sudáfrica. 


\section{Introduction}

In general, Mathematics performance of South African students has been highly influenced by poverty. A number of researchers including Fiske and Ladd (2004), and Van der Berg (2008) suggest environmental factors such as lack of resources that are associated with poverty in South Africa as a major influence on poor mathematics performance. This is particularly true for Black and Coloured learners who come from very poor families (Streak, $\mathrm{Yu}$ and Van der Berg, 2009). Furthermore, these learners often attend schools with high concentration of learners from similar socioeconomic background characteristics referred to as 'schools' socioeconomic status'. A number of studies in South Africa have revealed the significant impact of schools' socioeconomic status on students' performance (see Frempong, Reddy \& Kanjee, 2011; Spaull, (2013); Van der Berg, (2008). These studies highlight the vulnerability of poor learners in South Africa achieving success in mathematics-they come from homes with limited resources for learning, and attend schools with limited resources and peers in similar conditions at home.

Another vulnerability of these poor learners is the struggle with the language of instruction in school that is often different from the home language. In her analysis of South Africa TIMSS 1999, Howie (2003) demonstrated the significance of home language on successful mathematics learning. Howie (2003) and Feza-Piyose (2012) support the findings about the impact of language in mathematics achievement. Feza-Piyose (2012) goes further and argues for home language to be used as cultural capital for students instead of a barrier to access mathematics knowledge. All these studies and other mathematics education studies in South Africa highlight the vulnerability of poor learners in South Africa achieving success in learning mathematics.

Despite these vulnerabilities, quite a few poor learners attending poor schools are often successful. We refer to these learners as resilient-learners achieving success against all odds. We ask the question-what are the characteristics of these learners? We argue that understanding how these poor learners achieve success against all odds would help South African develop policies and intervention strategies to help address the socioeconomic inequalities in mathematics achievement. The next section of the paper explores the literature on how 
the concept of resilience has been used to explain how poor learners achieve success in schooling against all odds.

\section{Resilience and school effect}

Over the past decades, a number of studies on school effect have provided an understanding how schools functions to provide opportunities for all learners to succeed. One of the major findings of these studies conducted across 40 years to measure the effect of schools on achievement suggest that the extent to which a school commits itself to improve achievement contributed to $50 \%$ of between school variance, while peer influence accounted for $15 \%$ of the variance (See Lee \& Schute, 2010). In a recent research, Nicoll (2014) highlights the ways in which school culture - values, beliefs and practices - can transform and lead to successful schooling. Nicoll (2014) makes the case that successful schooling for the poor requires transformation and the development of reforms based on resilience and growth mindsets and their interactions with traditional academic skills - a resilience-focused, systemic paradigm.

This paradigm places emphasis on the schooling activities that protect learners from their vulnerabilities. Bernard (2004), notes that "one of the most important and consistent findings in resilience research is the power of schools, especially of teachers, to turn a child's life from risk to resilience (p. 65).” In addition to resilience, the work acknowledges the important role of teacher practices and relationship styles and both student and teacher social and emotion learning competencies - responsiveness to others, empathy, caring and communication for ensuring student achievement. At the root of these factors is the importance of promoting growth mindsets, upon teacher so that they might translate to students. These mindsets emphasize the idea that one can always learn, grow and become better (Dweck 2006) versus viewing learning, intelligence and capability as fixed.

Other research highlights a number of characteristics that have been identified from resilient students. Borman and Overman (2004) typify these characteristics as "underlying perseverance, strong will, and positive disposition of a resilient child" (p. 178). The literature indicates that students' active participation in educational activities, their mathematics selfefficacy, self-confidence, attitude towards school are characteristics possessed by resilient students (Borman and Overman, 2004; Eatmon, 2009; De Baca, 2010). De Baca (2010) lists additional characteristics such as motivation to succeed, ability to set goals, ability to handle stress and strong connections with adults and peers. Murray et al (2000) suggest six skills that 
students need to be acquired to become resilient such as confidence, making connections, setting goals, managing stress, increasing well-being and understanding motivation.

\section{The aims}

Despite this critical literature on resilience, we do not have studies in developing countries such as South Africa that inform policy options to improve learning outcomes for the poor. Our study attempts to fill this research gap by using a large scale data to define and profile resilient students and understand how these students achieve success despite their socioeconomic disadvantage. In particular, we are interested in factors that shape socioeconomic resilient students. We explored background characteristics such as gender and educational challenges, including experience with bullying, language barriers at home versus at school, and parental involvement in schooling. Finally, we investigate students' attitude towards learning, in particular mathematics, as a mechanism to understand how the soft skills shape students' ability to achieve despite their social and financial disadvantage. We hope that this understanding would inform policy decisions on how schools in South Africa should function to provide opportunities and capabilities for the children attending schools in poor communities to succeed. We argue that this understanding would greatly help the South African government's objective of providing quality education for all learners.

\section{Method}

\section{Participants}

Data for this paper was sourced from the TIMSS 2011 study conducted by the International Association for the Evaluation of Educational Achievement (IEA). TIMSS was first conducted in 1995 and every fourth year since then. South Africa took part in 1995, 1999, 2003 and 2011. From the population of 10,085 South African schools which offered grade 9 classes in 2011, a stratified random sample of 298 schools were selected by the IEA Data Processing and Research Centre. The sample was stratified by province, language of instruction (Afrikaans, English, or dual - both Afrikaans and English) and type of school (independent, public). In each sample school, a grade 9 class was randomly selected to participate in the study. A total of 11,969 grade 9 students participated in the 2011 TIMSS study for South Africa. These students responded to test items on mathematics and science that allowed us to 
estimate their achievement levels in both subjects. TIMSS employed Item Response Theory (IRT) to scale learners' responses setting the mean to 500 and a standard deviation of 100 .

An important aspect of the TIMSS design is the matrix-sampling approach where the test items covered the expected curriculum of the participating education systems. The items were then distributed into a set of 14 booklets. This approach ensured that the achievement tests represented the curricula of the participating countries involved in the study. Each participating country was given the opportunity to pilot the test tiems. The IRT estimate of students' achievement level involved plausible values where the average provided a reasonable estimate of learners' performance in the test.

\section{Procedure}

We characterized resilient students as those from poor families who attend schools with limited resources but are successful in school. In TIMSS, students responded to a questionnaire about their socioeconomic background characteristics. StudentSES was generated from students' responses to eighteen listed assets in the student questionnaire. Students were asked to indicate whether each of the listed assets was present at their homes (dichotomous variables yes/no response). Examining responses to these questions, frequency analysis was conducted on each listed asset. Missing values ranged from $2.3 \%$ to $7.1 \%$ across all assets. The variable, StudentSES, was generated by the calculation of the sum of all these assets. The scores were then standardized with a mean of zero and stdard deviation of one.

Students were then grouped into five poverty quintiles where the first quintile represented students with least assets and the fifth quintile represented students with most assets. In South Africa, schools are classified into poverty quintiles based on the communities where the schools are located. Schools located in the poorest communities are classified as quintile_1 while those in affluent communities are classified as quintile_5. The TIMSS data included a description of the poverty designation of schools allowing us to identify poor students in poor schools. In general schools designated as quintiles 1, 2 and 3 are classified as poor schools and often receive more resources from the government and students in these schools do not pay school fees (referred to as no-fee schools). We classified poor students as those with limited assets at home—quintiles 1 and 2. We used students' mathematics achievement of over a 352 score (the South Africa average achievement score) as a measure of success. Using cross 
tabulations, we classified these poor SES students who attend quintile 1, 2 and 3 schools who attend quintile 1, 2 and 3 schools who scored above the South average (352) on mathematics as resilient.

\section{Design and data analysis}

The TIMSS study covered both public and independent school types. Of all schools offering grade 9, learners in independent schools represented $3 \%$ of the total school population in South Africa in 2011. Since only public schools are classified into school poverty quintiles, we could identify resilient students in public schools only. Four groups of students were derived namely: resilient public school students (11\%); the rest of the public school students $(86 \%)$ which were further divided in two groups: public school students who performed above average (30\%) and public school students who performed below the average score of 352 points (56\%); and independent school students (3\%). The actual sample size and percentage distribution of the four groups are presented in table 1.

Table 1. Percentage distribution of the four identified groups

\begin{tabular}{|c|c|c|c|c|c|}
\hline & $\begin{array}{l}\text { Resilient } \\
\text { students (Perf: } \\
352 \text { and } \\
\text { above) }\end{array}$ & $\begin{array}{l}\text { High perf. } \\
\text { public school } \\
\text { students (Perf: } \\
352 \text { and } \\
\text { above) }\end{array}$ & $\begin{array}{l}\text { Low perf. } \\
\text { public school } \\
\text { students } \\
\text { (Below } 352 \\
\text { score points) }\end{array}$ & $\begin{array}{l}\text { Independent } \\
\text { school stu- } \\
\text { dents }\end{array}$ & $\begin{array}{l}\text { Survey popula- } \\
\text { tion }\end{array}$ \\
\hline Actual sample & 1223 & 4018 & 5808 & 920 & 11969 \\
\hline Percentage & 11 & 30 & 56 & 3 & 100 \\
\hline
\end{tabular}

We explored the following characteristics across these four groups: gender, how often the test language was spoken at home, students' attitudes towards learning Mathematics, bullying at school, highest level of parental education, and parental involvement in school homework at home. These characteristics have been associated with learning in the literature and thus should enable an understanding of the ability of learners that came from poor backgrounds to achieve academic success. Using simple cross tabulation analysisfor each group, we estimated the percentage of learners with these specific characteristics. This was followed by a chi-square test that indicated statistical significance $(p<.05)$ for all the variables. This is expected given the large sample size of the four groups (see Table 1). 


\section{Results}

We have presented our findings from the cross tabulation analysis in table 2 and figures 1 to 5.

Table 2. Percentage distribution of the four identified groups by selected characteristics

\begin{tabular}{|c|c|c|c|c|c|c|}
\hline $\begin{array}{l}\text { Description of } \\
\text { characteristic }\end{array}$ & Categories & $\begin{array}{l}\text { Resilient } \\
\text { students (Perf: } \\
352 \text { and } \\
\text { above) }\end{array}$ & $\begin{array}{l}\text { High perf. } \\
\text { public school } \\
\text { students (Perf: } \\
352 \text { and } \\
\text { above) }\end{array}$ & $\begin{array}{l}\text { Low perf. } \\
\text { public school } \\
\text { students } \\
\text { (Below } 352 \\
\text { score points) }\end{array}$ & $\begin{array}{l}\text { Independent } \\
\text { school stu- } \\
\text { dents }\end{array}$ & $\begin{array}{l}\text { Survey popula- } \\
\text { tion }\end{array}$ \\
\hline \multirow[t]{2}{*}{ Gender } & Girls & 52 & 49 & 46 & 49 & 48 \\
\hline & Boys & 48 & 51 & 54 & 51 & 52 \\
\hline \multirow{3}{*}{$\begin{array}{l}\text { Students like } \\
\text { learning } \\
\text { Mathematics }\end{array}$} & Like learning Mathematics & 63 & 52 & 29 & 39 & 41 \\
\hline & $\begin{array}{l}\text { Somewhat like learning } \\
\text { Mathematics }\end{array}$ & 30 & 33 & 54 & 41 & 44 \\
\hline & $\begin{array}{l}\text { Do not like learning Mat- } \\
\text { hematics }\end{array}$ & 7 & 15 & 17 & 20 & 15 \\
\hline \multirow{3}{*}{$\begin{array}{l}\text { Students value } \\
\text { learning } \\
\text { Mathematics }\end{array}$} & Value & 85 & 80 & 66 & 74 & 72 \\
\hline & Somewhat value & 12 & 17 & 25 & 21 & 21 \\
\hline & Do not value & 3 & 3 & 10 & 5 & 7 \\
\hline \multirow{3}{*}{$\begin{array}{l}\text { Students are } \\
\text { confident in } \\
\text { learning } \\
\text { Mathematics }\end{array}$} & Confident & 18 & 18 & 4 & 19 & 10 \\
\hline & Somewhat confident & 55 & 48 & 58 & 47 & 54 \\
\hline & Not confident & 26 & 33 & 38 & 35 & 35 \\
\hline \multirow{3}{*}{$\begin{array}{l}\text { Students } \\
\text { engage in } \\
\text { Mathematics } \\
\text { lessons }\end{array}$} & Engaged & 45 & 40 & 31 & 33 & 35 \\
\hline & Somewhat engaged & 51 & 50 & 58 & 53 & 54 \\
\hline & Not engaged & 4 & 10 & 12 & 14 & 10 \\
\hline \multirow[t]{9}{*}{ (15) Province } & Eastern Cape & 12 & 10 & 19 & 11 & 16 \\
\hline & Free State & 7 & 7 & 6 & 2 & 6 \\
\hline & Gauteng & 14 & 27 & 10 & 45 & 17 \\
\hline & KwaZulu-Natal & 27 & 17 & 26 & 14 & 23 \\
\hline & Limpopo & 15 & 9 & 20 & 14 & 16 \\
\hline & Mpumalanga & 9 & 7 & 7 & 4 & 7 \\
\hline & Northern Cape & 3 & 3 & 2 & & 2 \\
\hline & North West & 8 & 6 & 5 & 4 & 6 \\
\hline & Western Cape & 6 & 14 & 5 & 6 & 8 \\
\hline \multirow{4}{*}{$\begin{array}{l}\text { I like being in } \\
\text { school }\end{array}$} & Agree a lot & 88 & 70 & 78 & 62 & 76 \\
\hline & Agree a little & 10 & 22 & 15 & 28 & 17 \\
\hline & Disagree a lot & 1 & 5 & 4 & 8 & 4 \\
\hline & Disagree a little & 1 & 2 & 3 & 2 & 3 \\
\hline \multirow{4}{*}{$\begin{array}{l}\text { I feel like I } \\
\text { belong at this } \\
\text { school }\end{array}$} & Agree a lot & 60 & 54 & 58 & 51 & 57 \\
\hline & Agree a little & 30 & 30 & 23 & 29 & 26 \\
\hline & Disagree a lot & 6 & 11 & 12 & 12 & 11 \\
\hline & Disagree a little & 4 & 6 & 8 & 8 & 7 \\
\hline \multirow{4}{*}{$\begin{array}{l}\text { I would like a } \\
\text { job that invol- } \\
\text { ves using } \\
\text { mathematics }\end{array}$} & Agree a lot & 53 & 44 & 50 & 37 & 48 \\
\hline & Agree a little & 32 & 31 & 28 & 31 & 29 \\
\hline & Disagree a lot & 8 & 14 & 11 & 16 & 12 \\
\hline & Disagree a little & 7 & 12 & 11 & 15 & 11 \\
\hline
\end{tabular}


Table 2 shows that more than $50 \%$ of the resilient learners are girls indicating that girls were more likely to be resilient than boys. In all the other groups, the boys were in the majority. The table has also provided details of learner attitude towards Mathematics and the school environment. Our analysis revealed that resilient students had a very positive attitude towards studying Mathematics and towards their school. A very high percentage (63\%) of resilient students indicated that they like learning Mathematics - this value is $22 \%$ higher than the survey population's average and higher than the other three student groups. On a question about if they value learning Mathematics, $85 \%$ of resilient students; $80 \%$ of high performing public school; $66 \%$ of low performing public school; and $74 \%$ of independent school students responded positively. The data furthermore suggests that resilient students were more likely to engage in Mathematics lessons. Despite the very difficult and poor conditions experienced by resilient students at school, $88 \%$ (12\% higher than the population average) liked being in school; $63 \%$ indicated that they felt safe at school; $60 \%$ felt that they belonged at their specific school. The majority of resilient students (53\%) would like to have a job that involves using Mathematics.

Further analysis explored the age distribution of resilient learners. In South Africa, children often start grade 1 at the age of five or six. This means that if a child does not repeat a grade then we would expect this child to be about 14 or 15 at grade 9. Figure 1 shows that compared to the average age of grade 9 students, the age distribution of resilient students reflected a slightly younger group. The figure 1 indicates that low performing public school students were older than students in the other groups and the age profile of resilient students was similar to high performing public school and independent school students.

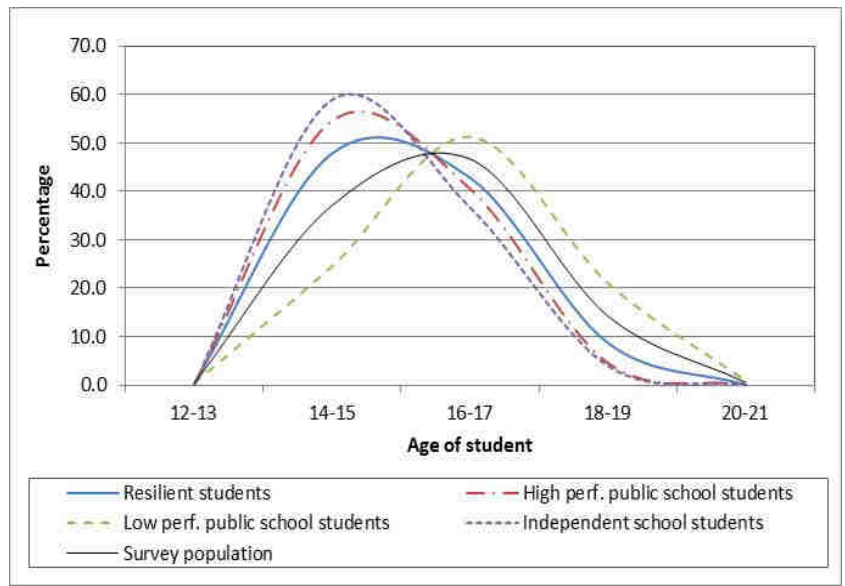

Figure 1. Age profile by identified groups 
Figure 2 shows that the frequency distributions for resilient and low performing public school students were similar while the distributions for independent and high performing public school students were quite similar. The figure indicates that most of the resilient learners and learners in low performing public schools do not regularly speak the language of the test at home.

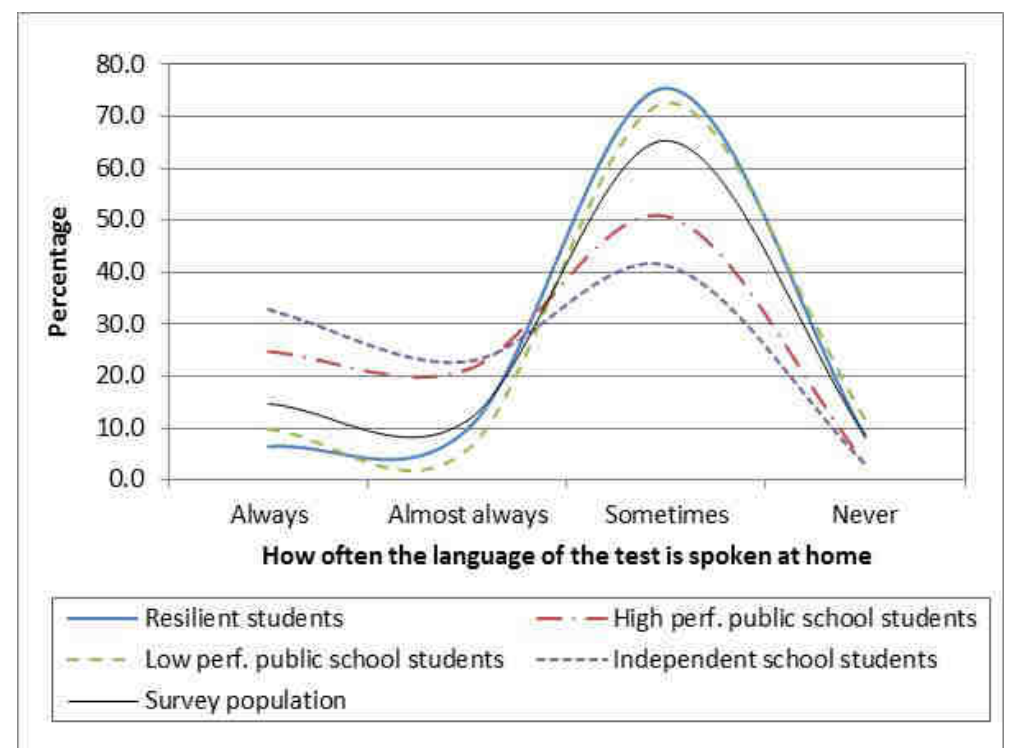

Figure 2. Language of test profile Age profile

South Africa has 11 official languages (see Figure 3). Figure 3 shows that isiZulu students tended to be more resilient than other language speakers - 30\% of the resilient students were isiZulu speakers which was a much higher percentage than the average proportion of isiZulu speakers in the survey population (24\%) and also much higher than the proportion of isiZulu speakers in the other groups. This result was confirmed by an analysis on the provincial distribution of the different student groups (see Table 1 in appendix: (15)). 27\% (much higher than the average proportion of the survey population of 23\%) of resilient students came from KwaZulu-Natal which is the province where isiZulu is most frequently spoken by residents. 


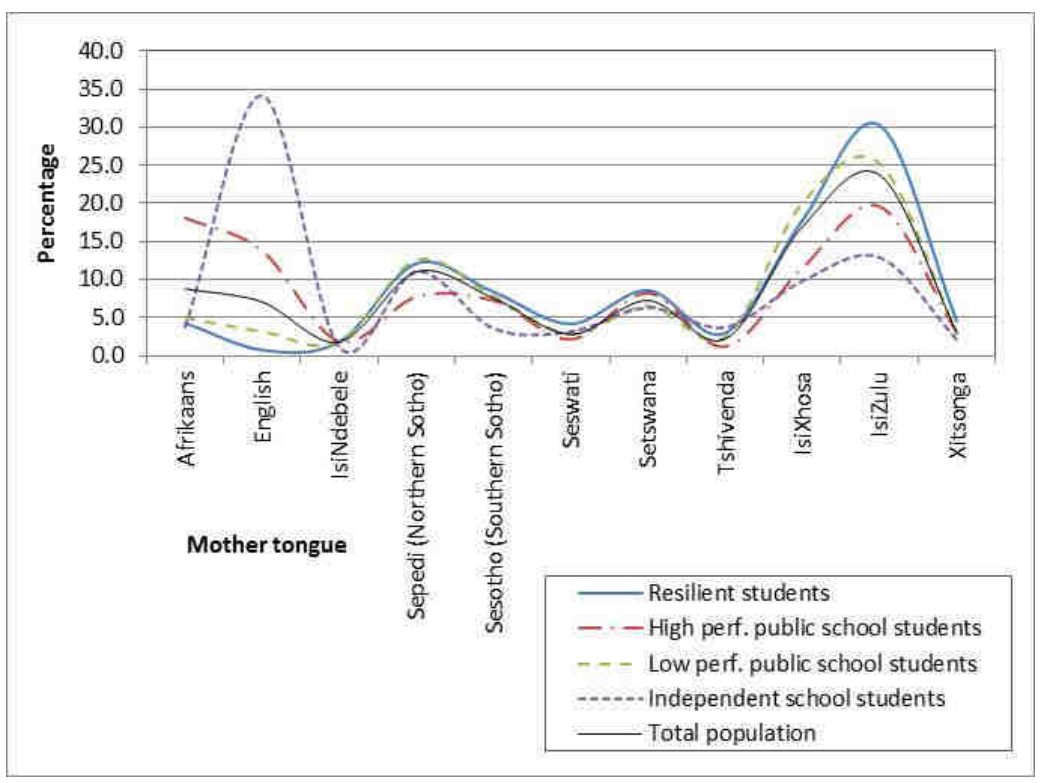

Figure 3. Mother tongue profile

The Student-bullied-at-school index was developed from six variables in the TIMSS data relating to the frequency of different bullying incidents experienced by students at school. The data suggests that $79 \%, 62 \%, 82 \%$ and $58 \%$ of students were bullied among resilient, high performing public school, low performing public school and independent school students, respectively. The results suggest that most resilient learners (about 80\%) have been bullied in school similar to the percentage of learners in low performing public school students. See Figure 4.

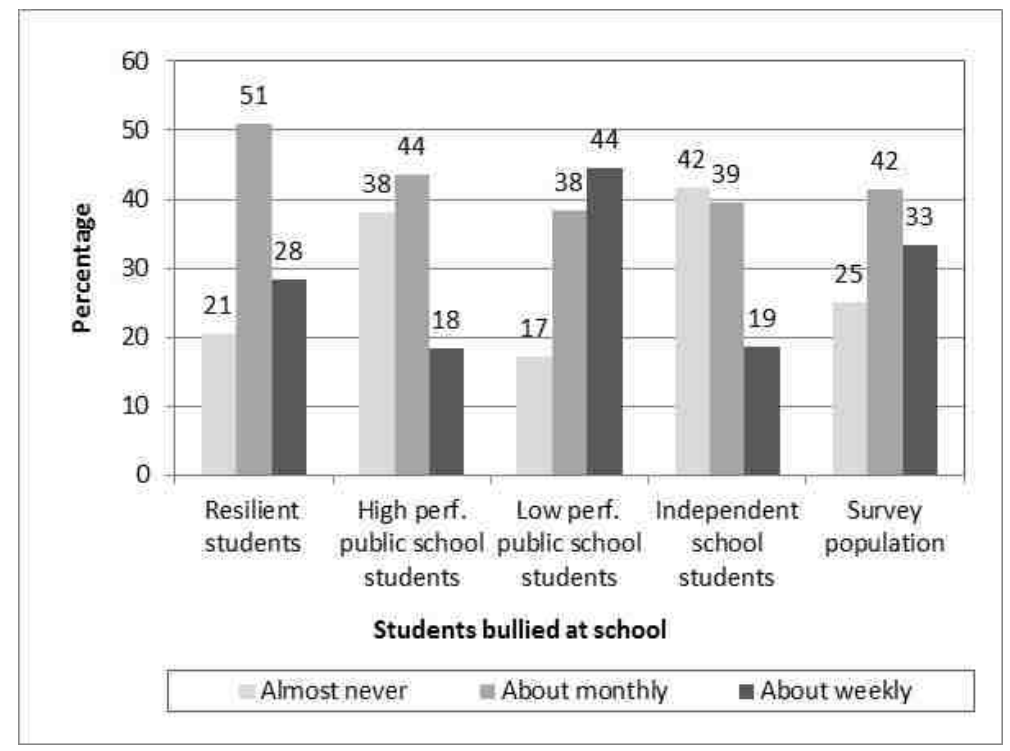

Figure 4. School disciplinary climate profile 
Our analysis also profiled the parental education of resilient learners. The findings are presented in Figure 5. The figure shows that the group of resilient students' parents had the lowest qualifications compared to the other groups.



Figure 5. Parent education profile

No significant differences between the four student groups could be identified. It seemed as if parental involvement did not play a significant role in the resilience and performance of students.

\section{Discussion and Conclusions}

Altogether our analysis has highlighted a number of characteristics profiling resilient students in South Africa. The analysis reveals that resilient student in South Africa tend to be girls who speak their native language, particularly those from the province of KwaZulu Natalthat speak Zulu at home and thus not the language of test (English). Additionally, we find that other factors such as student positive attitude towards mathematics and school more generally, as well as valuing the learning of mathematics and aspiring to have a job that involves mathematics are important characteristics of resilient learners. 
This work has important implications on the study of academic achievement among low SES learners in developing countries. The findings call for further research in eliciting the main factors that contribute in favouring girls versus boys in becoming resilient. Given the persistent cultural and social practices that limit girls in these contexts, the ability for girls to be resilients is impressive. However, it also raises the question about the fact that girls have to be resilient in order to achieve. It is critical that more research is conducted to ensure that girls do not have to work harder to achieve the same results as their male counterpart.

The results also shed more light on the debate about the importance of language for educational achievement. The language characteristic has been highly researched in South Africa and more studies favour the use of mother tongue to mediate conceptual learning of mathematics (Setati, 2005, Setati and Barwell, 2006, Feza, 2012, Webb, 2009). Our findings provide additional support for the use of mother tongue at home for improving the educational success of disadvantaged learners.

Finally, the work contributes to research on the importance of non-cognitive skill development. As emphasized by Borman and Overman (2004) and Eaton (2009), when schools create the conditions that make learning valued by students and provide tools that promote positive learning identities, students develop skills for learning that contribute to academic success. Similarly, our findings demonstrate the importance of a positive mindset towards learning, in particular mathematics, but more generaly towards schools. Ultimately, the implications of this work can shape important educational policy issues facing South Africa and similar countries across the globe. Most importantly, the paper demonstrates the need for the South Africa education policy to direct attention to schooling practices that help learners develop these skills.

The current South Africa policy to improve schooling outcomes for the poor seems to emphasise the lack of resources in schools serving these learners. The general assumption is that improved access to resources to school serving the poor would lead to successful schooling outcomes of these learners. While we encourage continue funding for resources, our findings suggest the need to focus our efforsts on initiative that enable schools to develop caring and enabling environments for students to develop confidence in learning. By focusing on how students succeed from resilient perspective, we can get closer to institutionalizing these 
factors so that all students can achieve regardless of their background. In the end, a student should not have to be resilient in order to achieve, they should simply have the resources and support they need to be successful.

\section{References}

Benard, B. (2004). Resiliency: What we have learned. San Francisco, CA: WestEd.Borman, G. D., \& Overman, L. T. (2004). Academic Resilience in mathematics among poor and minority Students. The Elementary School Journal, 104(3), 177-195. http://dx.doi.org/10.1086/499748

De Baca, C. (2010). Resilency and Academic Performance. A Review of the Literature: Scholar Centric retrieved at www.ScholarCentric.com on 2 October 2013.

Dweck, C.S. (2006). Mindset: the new psychology of success. New York: Ballentine Books

Eatmon, D. (2009). A Case Study of Resilience Based on Mathematics Self-Efficacy and Social Identity. Proceedings of the $31^{\text {st }}$ annual meeting of the North American Chapter of the International Group for the Psychology of Mathematics Education, Swars, S. L., Stinson, D.W., \& Lemons-Smith, S. (Eds). Atlanta: GA.

Feza-Piyose, N. (2012b). Language a cultural capital for conceptualizing mathematics knowledge. International Electronic Journal of Mathematics Education, 7(2), 62-79.

Frempong et al (2011). Exploring equity and quality education in South Africa using multilevel models. Compare: A Journal of Comparative and International Education, 41(6), 819-835.

Howie, S. J. (2003). Language and other background factors affecting secondary pupils' performance in Mathematics in South Africa. African Journal of Research in Mathematics, Science and Technology Education, 7(1), 1-20.

Lee, J., \& Shute, V. J. (2010). Personal and social-contextual factors in K-12 academic performance: An integrative perspective on student learning.Educational Psychologist, 45(3), 185-202. doi: 10.1080/00461520.2010.493471

Murray Nettles, S., Mucherah, W., \& Jones, D. S. (2000). Understanding resilience: The role of social resources. Journal of Education for Students Placed at Risk (JESPAR), 5(12), 47-60.

Nicoll, W. G. (2014). Developing transformative schools: A resilience-focused paradigm for education. International Journal of Emotional Education, 6(1), 47. 
Setati, M. (2005). Mathematics education and language: Policy, research and practice in multilingualSouth Africa. Researching mathematics education in South Africa (pp. 73109). Capetown, South Africa: HSRC Press.

Setati, M., \& Barwell, R. (2006). Discursive practices in two multilingual mathematics classrooms: An international comparison. African Journal for Research in Mathematics, Science and Technology Education. 10(2), 27-38.

Spaull, N. (2013). Poverty \& privilege: Primary school inequality in South Africa. International Journal of Educational Development, 33(5), 436-447.

Streak, J. C., Yu, D., \& Van der Berg, S. (2009). Measuring child poverty in South Africa: Sensitivity to the choice of equivalence scale and an updated profile. Social Indicators Research, 94(2), 183-201.

Van der Berg S (2008). How effective are poor schools? Poverty and educational outcomes in South Africa. Studies in Educational Evaluation, 34(3), 145-154. 